\title{
Ionizing Radiations $(\alpha, \beta, \gamma)$ Effects on CdS / P-Si Heterojunction Solar Cell for Electrical and Optical Properties
}

\author{
Ayman A. El-Amin ${ }^{1,2}$ \& Magdi H. Saad ${ }^{1,3}$ \\ ${ }^{1}$ Faculty of Science, Physics Department, Taibah University, Yanbu, KSA \\ ${ }^{2}$ Faculty of Science, Department of Physics, Aswan University, Aswan, Egypt \\ ${ }^{3}$ Physical department, Sudan University of Science and Technology, Khartum, Sudan \\ Correspondence: Ayman A. El-Amin, Faculty of Science, Physics Department, Taibah University, Yanbu, KSA. \\ Tel: 966-59-647-5021. E-mail: aaelamin2000@yahoo.com
}

Received: October 16, 2017

Accepted: December 7, 2017

Online Published: December 29, 2017

doi:10.5539/jmsr.v7n1p20

URL: https://doi.org/10.5539/jmsr.v7n1p20

\begin{abstract}
The effect of ionizing radiations $(\alpha, \beta, \gamma)$ in $\mathrm{CdS} / \mathrm{p}$-Si heterojunction solar cells are discussed in this paper. The short-circuit current density parameters before $\gamma$ irradiation conditions have been improved up to $35 \mathrm{~mA} / \mathrm{cm}^{2}$ and after $\gamma$ irradiation was $30 \mathrm{~mA} / \mathrm{cm}^{2}$. The open circuit voltage before $\gamma$ irradiation was 0.59 and $0.565 \mathrm{~V}$ after $\gamma$ irradiation. The limitations of these devices were discussed by investigating the dependence of electrical and efficiency parameters in function of radiation time. The efficiency of the cell before radiation was equal to (11.2\%) whenever, after the impact of both $\alpha, \beta$ and $\gamma$ was follows, 4.7, 4.9, and 5.1\% respectively. The fill factor before and after $\gamma$ irradiation was 54.5 and $53 \%$. Studying and analyzing the cells using the I-V, with the change of time rate of $\gamma$ radiation played a critical role in reducing the efficiency of solar cells. The campaign was carried out with different doses of a series of solar cells by exposing them to different time. The deterioration parameters of $\mathrm{CdS} / \mathrm{p}$ Si solar cells by $\gamma$ radiation led to strongly supports the results of minority carrier lifetime, which clearly showed diminishing minority carrier lifetime with increasing radiation dose.
\end{abstract}

Keywords: n-CdS/ P-Si Cells Performance, $\gamma$-radiation Effects, Electrical and Photovoltaic Characteristics solar cell, spectral photo current

\section{Introduction}

The electrical characteristics of silicon solar cells are affected by environmental condition. During operation of photovoltaic solar cells, they are exposed to radiation such as used in space systems and satellites. The irradiation of solar cells by high-energy levels of radiation in the form of $\gamma$ rays, neutrons, charged particles, etc. led to radiation defects and electrical damage in the solar cells bulk and results a significant degradation of the electrical parameters of silicon solar cells (Diab, Ibrahim, \& El-Mallawany, 2013; Razykov et al., 2011). The lifetime and performance of the solar cells was limited by the amount of radiation damage.

When silicon solar cells irradiated with gamma rays, two types of radiation damage occur within it: displacement damage and ionization effects. Displacement damage is the movement of atoms from their initial location in the crystal lattice to another placement that results a defect in the crystal lattice of solar cells. Ionization effect is the generation of electron-hole pairs in the bulk of solar cell. The eject electrons from the atoms of the crystal results a track of ionized atoms in the solar cells crystal. These defects mostly act as recombination points that decreased the diffusion length and life time of minority carrier as well as increased internal parameters of cells. Output parameters of solar cell such as maximum output power, fill factor, efficiency, short circuit current, and open circuit voltage strongly depend on internal parameters of solar cells such as series resistance, $\mathrm{R}_{\mathrm{S}}$, saturation current, I0 and ideal factor, $n$. it has been proved that increasing each of above internal parameters of solar cell causes that the output characteristics of solar cells decreased (Alurralde et al., 2004; Madatov, 2014; VASTC, Vujisic, Loncar, \& Osmokrovic, 2007).

Conservative single-junction semiconductor solar cells only effectively convert photons of energy close to the semiconductor band gap $\mathrm{E}_{\mathrm{g}}$ as a result of the mismatch between the incident solar spectrum and the spectral absorption properties of the material (Vasic, Vujisic, Stankovic, \& Jovanovic, 2010). Photons with energy $E_{\mathrm{ph}}$ smaller than the band gap are not absorbed. Photons with energy $\mathrm{E}_{\mathrm{ph}}$ larger than the band gap is absorbed, but the excess energy $\mathrm{E}_{\mathrm{ph}}{ }^{-}$ 
$\mathrm{E}_{\mathrm{g}}$ is not used effectively due to thermalization of the electrons. Several routes have been proposed to overcome these fundamental spectral losses that can account from as much as $50 \%$. All these methods or concepts, which are referred to as Third Generation(3G) photovoltaic (A El-Amin \& Ibrahim, 2012), concentrate on a better exploitation of the solar spectrum, e.g., intermediate band gaps (El-Mongy, Belal, El Shaikh, \& El Amin, 1997), quantum dot concentrators (Madatov, 2014) and down- and up-converters (Trupke, Green, \& Würfel, 2002).

\section{Experimental Work}

Two-inch of diameter the substrate materials are- oriented, p-type silicon wafers with a resistivity of $(1.4-2.0 \Omega . \mathrm{cm})$, corresponding to a doping density of (4-6) $\times 10^{15} \mathrm{~cm}^{-3}$. These wafers were etched using $\mathrm{CP}_{4}$ etching solution for (2) min, $\left(\mathrm{CP}_{4}\right.$ etching solution is prepared by adding $20 \mathrm{~mL}$ of $\mathrm{HF}$ acid to $30 \mathrm{~mL}$. Acetic acid and $60 \mathrm{~mL}$ concentrated $\mathrm{HNO}_{3}$ ). After etching, the Si-wafers were washed for $5 \mathrm{~min}$ by distilled water, and then by ethyl alcohol.

Film of CdS were evaporated onto the Si-wafers by using Cooting unit Edward type (E306A), Evaporation was carried out at pressure $\left(10^{-5} \mathrm{Torr}\right)$ in vacuum, to coated one side of the Si-wafers by $\mathrm{n}$-CdS thin film. The CdS thin film side, was over coated by an indium mesh to be used as grid electrode. After the CdS: In film Coated, the ohmic rear contact was fabricated by vacuum evaporation of Indium silver, and Aluminum electrodes. Then the front electrode was made by evaporating a Al metal grid, through a metal shadow mask. Finally, CdS/p-Si Heterojunction were annealed for two hours $\left({ }^{3} \mathrm{H}\right)$ at 550k to complete the Junction formation. Sample irradiation was carried out using a ${ }^{60} \mathrm{Co}$ gamma source model ISSLEDOVATEL manufactured by Russian irradiator and located at NCRRT, Vienna. The dose rate was $910 \mathrm{kGy} / 100 \mathrm{~min}$ and the temperature during irradiation was about $30^{\circ} \mathrm{C}$. Irradiation doses by $\gamma$-radiation with different doses (500, 1400, $\left.1900 \mathrm{M} \mathrm{Rad}\right)$.

\section{Results and Discussion}

\subsection{CdS/ p-Si Solar Cell Photovoltaic and Electrical Characteristics}

Photovoltaic cells electrical characteristics were investigated in the dark and under different bias light conditions. The solar cell parameters, short circuit current density $\mathrm{I}_{\mathrm{sc}}$, open circuit voltage $\mathrm{V}_{\mathrm{oc}}$, and maximum out putted power $\left(\mathrm{P}_{\mathrm{m}}\right)$ were determined. During dark I-V measurements, a light-proof cover shields the cell under test. The dark I$\mathrm{V}$ curve is measured in forward and reverse directions as shown in Figure 1.

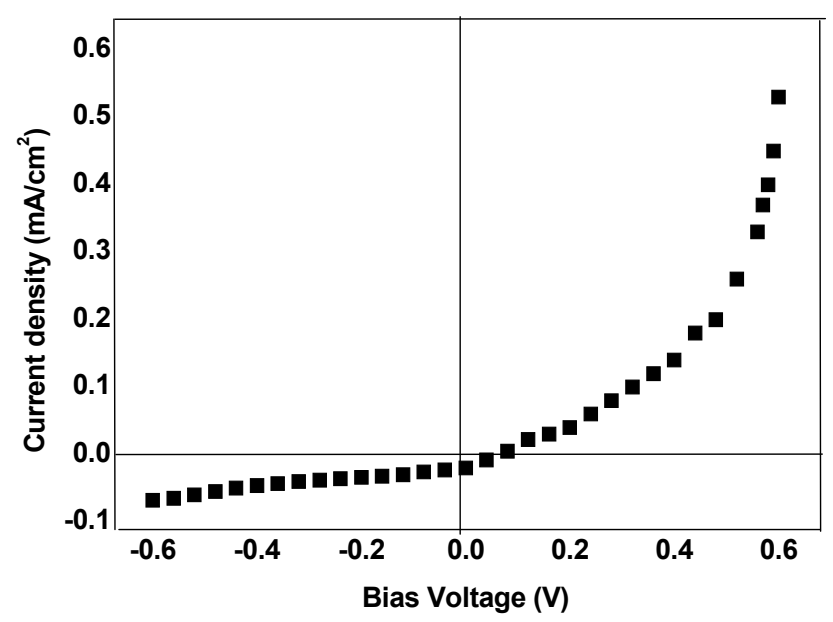

Figure 1. Current - voltage characteristic in dark

\subsection{Impact of Time of Irradiation on Electrical Performance}

The influence of time of radiation investigated on solar cell characteristics. The time of radiation is a critical factor effecting cell performance. Ionization occurs whenever the alpha particle is sufficiently close to electron to pull it out from orbit though coulomb attraction. Each time this occurs, the alpha $(\alpha)$ ( loses kinetic energy and is thus slowed. They $\alpha$ also loses kinetic energy by exciting orbital electrons with interactions that are insufficient to cause ionization. As it becomes slowed, the alpha has tendency to cause ionization at an increasing rate. As the alpha nears to the end of its track, its rate of ionization peaks and within very short distance, it stops, collects two electrons and becomes helium atom. Since alphas are low in penetration ability, they themselves are usually not hazardous for external exposure, unless the alpha-emitting nuclide is deposited to organism. When internally 
deposited, $\alpha$ particles are often more damaging than most other types of particles because comparatively large amounts of energy are deposited within a very small volume of tissue. Beta $(\beta)$ particles also cause excitation of external orbital electrons, which in turn leads to the emission of ultraviolet photons. The ultimate fate of a $\beta$ particle depends upon its charge. A negatively charged $\beta$ particle, after its kinetic energy has been spent, either combines with a positively charged ion, or becomes a "free electron". Positrons, however, have a different fate. In spite of the fact that they dissipate their kinetic energy just like $\beta$ particles through ionization and excitation, they cannot exist at rest in the vicinity of the electrons. When a positron has been slowed sufficiently, it will be attracted to the opposite charge of an electron. The interaction of photons ( $\gamma$-quantum) with matter involves several distinct processes. The relative importance and efficiency of each process is strongly dependent upon the energy of the photons and upon the density and atomic number of the absorbing medium.

Both $\mathrm{V}_{\mathrm{oc}}$ and $\mathrm{I}_{\mathrm{sc}}$ are dependent on the time of radiation for all solar cell used. figure 2 shows, as the time of radiation $(5,10,20,30 \mathrm{~min})$ decrease, the short circuit current $\mathrm{I}_{\mathrm{sc}}$ and open-circuit voltage $\mathrm{V}_{\mathrm{oc}}$ over a wide range of illuminated light time intensity is observed to be decrease, which is due to the low bulk diffusion length, electrons generated near the rear side of the solar cell have a low probability for collection. Due to the high internal area reflection, the total generation is hardly reduced by time of radiation. But the generation takes place closer to the junction and that will increase the collection probability. It shows that time of radiation best range is $\sim 5 \mathrm{~min}$. The electrical parameters of the different fabricated solar cells and different radiation source are presented in table (1). These parameters were obtained from (I-V) illuminated characteristics curve as a function of time of radiation.

Table 1. Electrical parameters of fabricated solar cells as a function of thickness before and after $\gamma-\beta$, and $\gamma$ Irradiation

\begin{tabular}{|c|c|c|c|c|c|c|c|c|c|}
\hline \multirow{2}{*}{$\begin{array}{l}\text { Time of } \\
\text { radiation }\end{array}$} & \multirow{2}{*}{$\begin{array}{l}\text { Type } \\
\text { radiation }\end{array}$} & \multicolumn{2}{|c|}{$\mathrm{V}_{\text {oc }}(\mathrm{mV})$} & \multicolumn{2}{|c|}{$\mathrm{J}_{\mathrm{sc}}\left(\mathrm{mA} / \mathrm{cm}^{2}\right)$} & \multicolumn{2}{|l|}{ F.F(\%) } & \multicolumn{2}{|l|}{$\eta(\%)$} \\
\hline & & Before & After & Before & After & Before & After & Before & After \\
\hline \multirow{3}{*}{$5 \mathrm{~min}$} & $\gamma$ & 490 & 425 & 28 & 21 & 33.6 & 48.6 & 4.8 & 3.6 \\
\hline & $\beta$ & 490 & 405 & 28 & 19 & 33.6 & 46.2 & 4.8 & 3.44 \\
\hline & $\alpha$ & 490 & 395 & 28 & 19 & 33.6 & 44.5 & 4.8 & 3.35 \\
\hline \multirow{3}{*}{$10 \mathrm{~min}$} & $\gamma$ & 520 & 500 & 30 & 23 & 42 & 50.4 & 6.8 & 4.3 \\
\hline & $\beta$ & 520 & 488 & 30 & 20 & 42 & 47 & 6.8 & 3.8 \\
\hline & $\alpha$ & 520 & 478 & 30 & 19 & 42 & 45.8 & 6.8 & 3.7 \\
\hline \multirow{3}{*}{$20 \mathrm{~min}$} & $\gamma$ & 560 & 528 & 33 & 25 & 47 & 52.3 & 9.2 & 4.5 \\
\hline & $\beta$ & 560 & 512 & 33 & 23 & 47 & 49.5 & 9.2 & 4.1 \\
\hline & $\alpha$ & 560 & 498 & 33 & 21 & 47 & 47 & 9.2 & 4.11 \\
\hline \multirow{3}{*}{$30 \mathrm{~min}$} & $\gamma$ & 590 & 555 & 35 & 28 & 53.9 & 53 & 11.2 & 4.9 \\
\hline & $\beta$ & 590 & 548 & 35 & 24 & 53.9 & 52.2 & 11.2 & 4.7 \\
\hline & $\alpha$ & 590 & 521 & 35 & 22 & 53.9 & 50.6 & 11.2 & 4.3 \\
\hline
\end{tabular}

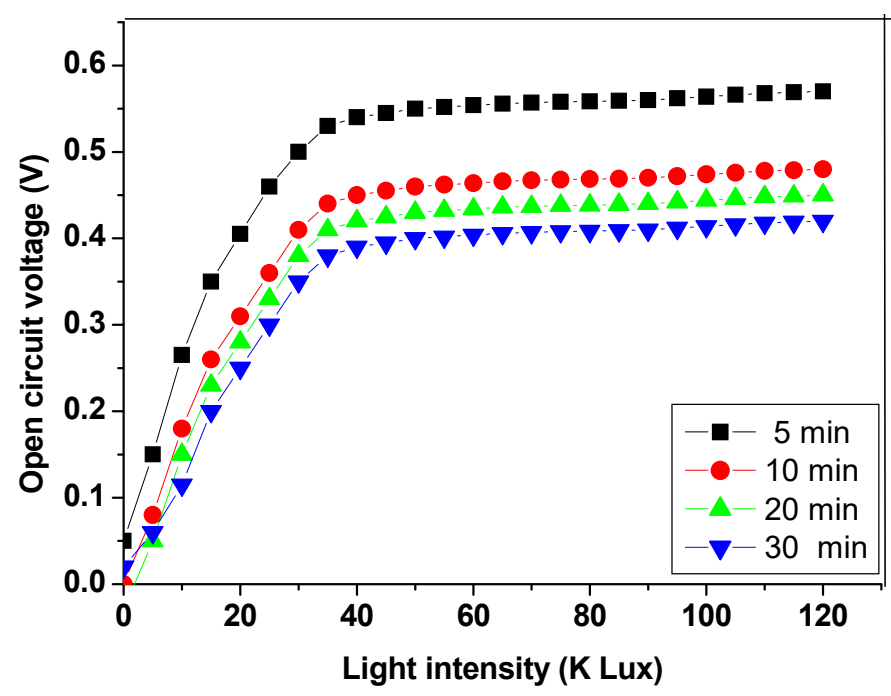

Figure 2. Open circuit voltage curve as a function of light intensity for different time of radiation 


\subsection{Impact of Light time Intensity on Electrical Performance}

In fact the solar cell with radiation time $(5 \mathrm{~min})$ has a much greater spectral response under fluency of light time intensity, due to it can absorbed more of the electromagnetic spectrum than the other thinner ones, and thus has the capacity to generate larger currents. Figure 2 shows the direct result, an increase in short circuit current density as the light time intensity increase, while as open-circuit voltage is largely unaffected all over light time intensity range and wavelengths incident, which means that, $\mathrm{V}_{\mathrm{oc}}$ increase up to $(20 \mathrm{k} \mathrm{Lux})$ as incident light time intensity increase, more than $20 \mathrm{k}$ Lux, Voc stays constant, relatively to the short circuit current density. The electrical parameters of the different fabricated solar cells and different source radiation are presented in table (1). These parameters were obtained from(I-V) illuminated characteristics curve as a function of rate time radiation .Finally for most studied solar cells, the short-circuit current density shows a linear relationship with the incident light time intensity (Radychev et al., 2011; Xie, Kolb, Li, Basché, \& Mews, 2005). The open-circuit voltage and fill factor is much weaker dependant on the light time intensity (Koster, Mihailetchi, Xie, \& Blom, 2005; Ringel, Smith, MacDougal, \& Rohatgi, 1991).

\subsection{Spectral Response Measurements}

The spectral response for tested solar cells shows in figure 3 results which were processed with different radiation time $(5,10,20,30 \mathrm{~min})$. As it can be seen, for whole cells, the optical properties of solar cells are almost the same trend but with different wavelengths range (i.e), as the solar cell radiation time decrease, the maximum $\mathrm{I}_{\mathrm{sc}}$ value shifted towards the blue wavelength region. It can be noted that the spectral response at the long wave length decrease with the reduction in the radiation time. Light transmission loss due to an insufficient absorption layer, and carrier recombination loss at the back contact, due to the probable presence of defect at the junction can be considered to be responsible for the total current loss in such thin films.

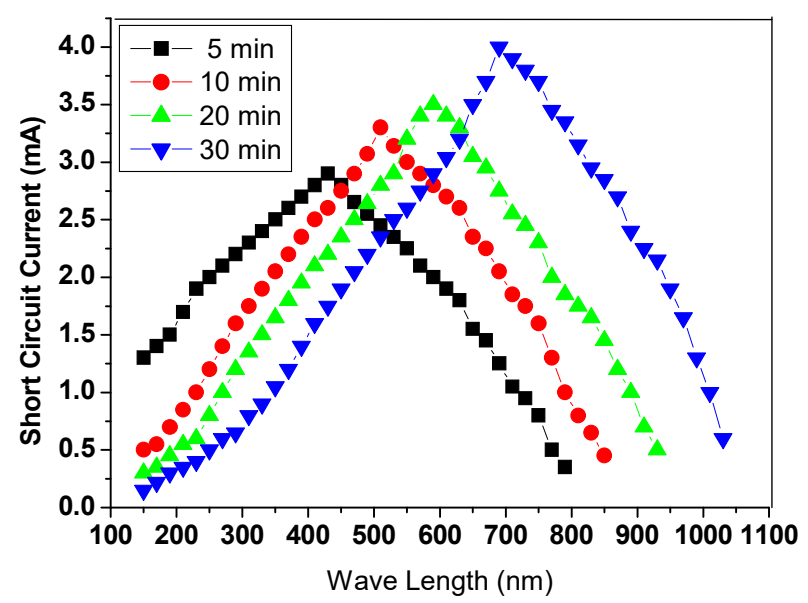

Figure 3. Spectral response for different time of radiation

\subsection{Impact of Solar Radiation Variation}

The above model includes two subsystems: one that calculates the PV cell photocurrent which depends on the radiation and the temperature according to equation (1) (Nema, Nema, \& Agnihotri, 2010).

$$
I_{p h}=\left[I_{s c}+K_{i}(T-298)\right] G / 1000
$$

where $\mathrm{K}_{\mathrm{i}}=0.0017 \mathrm{~A} /{ }^{\circ} \mathrm{C}$ is the cell's short circuit current temperature coefficient and $\mathrm{G}$ is the solar radiation $\left(\mathrm{W} / \mathrm{m}^{2}\right)$.

The PV cell current is strongly dependent on the solar radiation as it can be seen from Figs.(4,5). However, the voltage has a $50 \mathrm{mV}$ increase as the solar radiation increased from 400 to $1000 \mathrm{~W} / \mathrm{m}^{2}$.

Voltage-current characteristics of four solar cell samples before and after various doses of gamma radiation at under AM1.5 illumination condition have been showed in figure 6. As can be seen, I-V characteristics of cells deteriorated with increasing gamma irradiation. From figure 6, fundamental parameters of solar cells such as open circuit voltage $\left(\mathrm{V}_{\mathrm{oc}}\right)$, short circuit current $\left(\mathrm{I}_{\mathrm{sc}}\right)$, fill factor $(\mathrm{ff})$ and efficiency $(\eta)$ could be extracted (Ali, Gouveas, Hasan, Zaidi, \& Asghar, 2011; Nikolić, Stanković, Timotijević, Rajović, \& Vujisić, 2013; Vasic, Osmokrovic, Marjanovic, \& Pejović, 2013). 


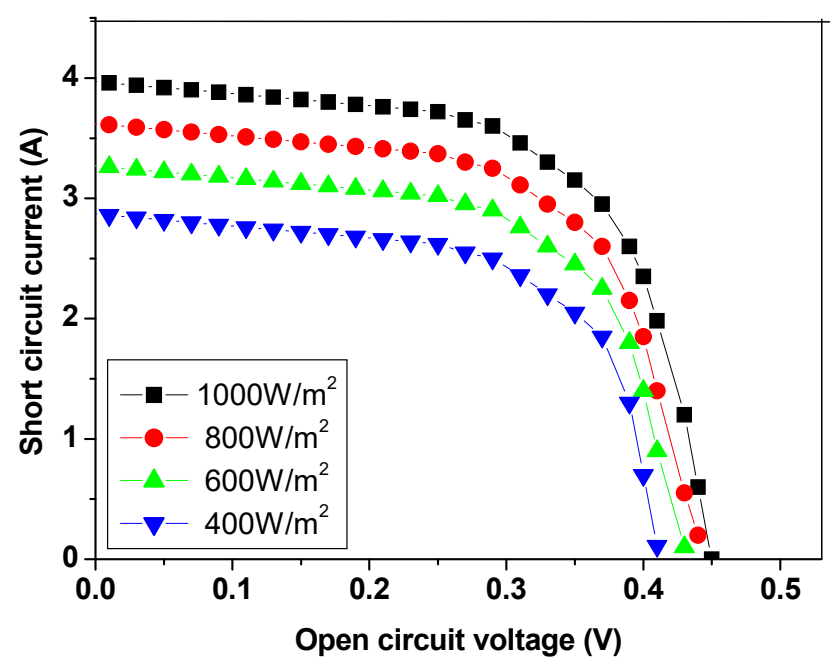

Figure 4. $I-V$ curves for different solar radiations.

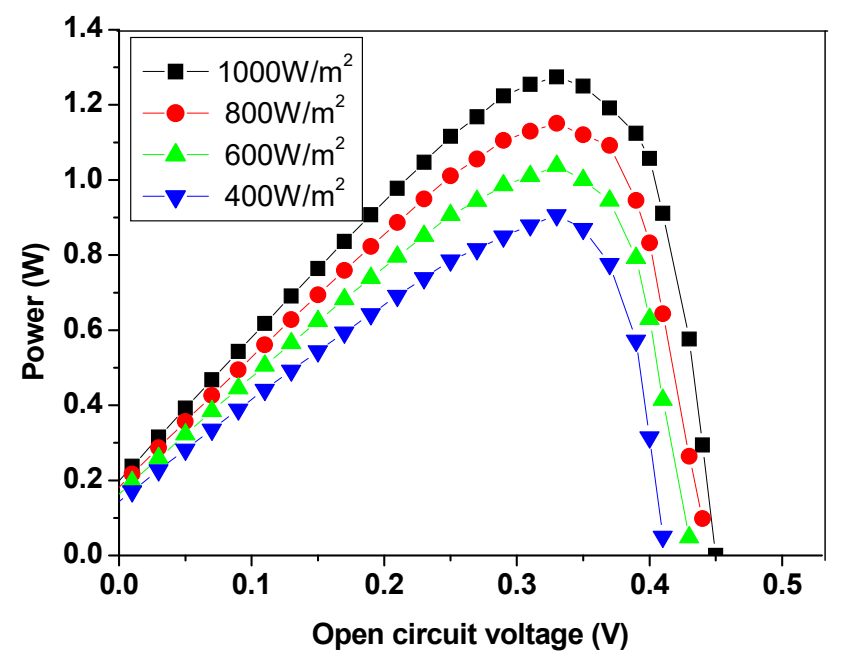

Figure 5. $P-V$ curves for different solar radiations.

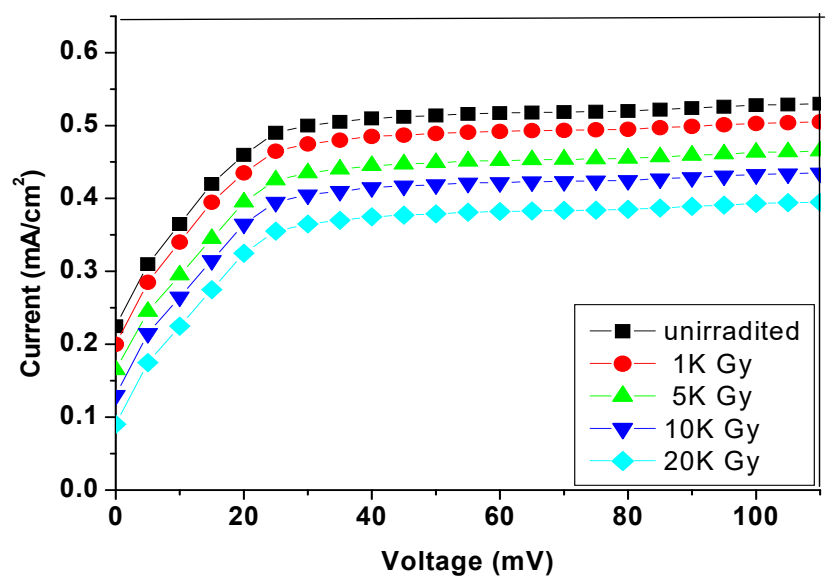

Figure 6 . The $I-V$ characteristics of silicon solar cell irradiated with various doses of gamma radiation 
It was found that the degradation of the solar cell parameters is dependent on the gamma radiation dose and the irradiation has affected the solar cell parameters to a certain extent. There is no substantial variation in the fill factor, which in some cases showed increased or relatively steady values. According to the results, the gamma radiation causes a significant Reduction in the short circuit current and efficiency while the open circuit voltage is slightly reduced (Ashry \& Fares, 2012; Imaizumi, Taylor, Hisamatsu, Matsuda, \& Kawasaki, 1997; Saad, 2002; Sze, 1981).

The decrease in short circuit current and other fundamental parameters of solar cells under gamma radiation is mainly related to the minority carrier life time. The minority carrier lifetime of a solar cells, is the average time which a minority carrier can spend in an excited state after electron-hole generation before it recombines. The lifetime of minority carriers is sensitive to the radiation induced defects that mostly act as recombination points (Ali et al., 2011; Vasic et al., 2013). The lifetime is related to the recombination rate by equation 2:

$$
\tau=\Delta \mathrm{n} / \mathrm{R}
$$

Where $\tau$ is the minority carrier lifetime, $\Delta \mathrm{n}$ is the excess minority carriers concentration and $\mathrm{R}$ is the recombination rate.

The variation of minority carrier lifetime of silicon solar cell samples before and after gamma irradiation as a function of dose is shown in figure 7.

Minority carrier diffusion length is a more applicable parameter for solar cell analysis. With increasing the gamma radiation dose, the electron-hole recombination points increases Therefore the concentration of minority carrier traps will increase. Decrease in the minority carrier lifetime reduced the solar cells electrical properties (Kuendig, Goetz, Shah, Gerlach, \& Fernandez, 2003).

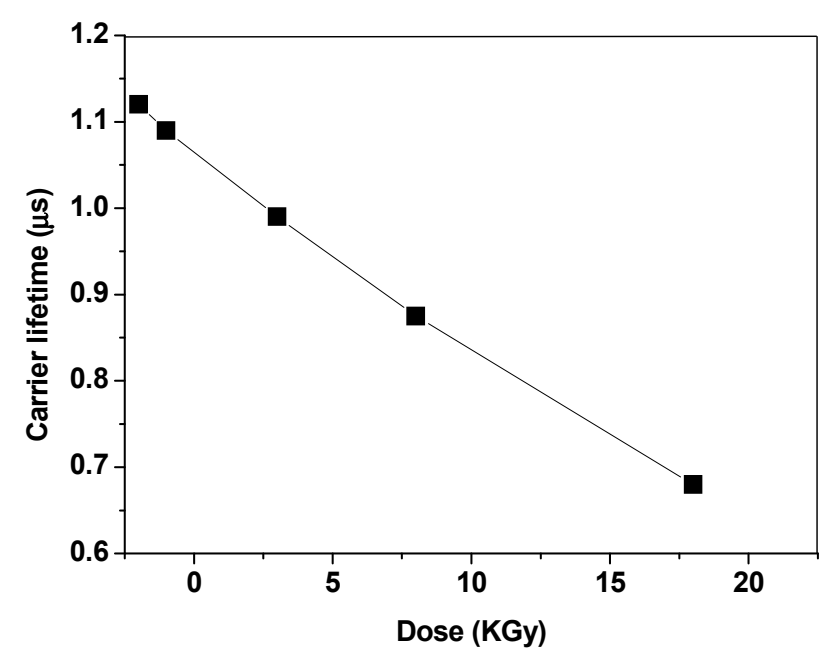

Figure 7. The variation of minority carrier lifetime with various doses of gamma irradiation.

\section{Conclusions}

The influences of various conditions in the $\mathrm{CdS} / \mathrm{p}$-Si solar cell performance was investigated. The fabrication of CdS/P-Si Heterojunction by physical thermal evaporation method has been reported The effect of time rate radiation was observed. The thin $\mathrm{CdS} / \mathrm{p}$-Si cell. Time redaction leads to the typically reduced spectral response in the infrared, and the wavelength which has the maximum spectral response was shifted towards the shorter wavelength, as the time radiation decrease. In addition the radiation hardness of solar cell performance. The effect of time radiation was observed. The effects of radiation noted a decrease in electrical performance as the radiation dose increase. Parameters such as donor concentration in CdS, as well as current - voltage, and capacity voltage are described. The efficiency of the best performance solar cell CdS/ Si approached around $11.2 \%$.

The electric properties deterioration of solar cells under gamma irradiation was observed when the gamma dose was increased (1 to $20 \mathrm{KGy}$ ). Except for the fill factor, which in some cases showed increased or relatively steady values, $\gamma$ radiation causes a significant Reduction in the Isc and $\eta$ while the Voc is slightly reduced. The decrease in short-circuit current and other fundamental parameters is mainly related to the minority carriers lifetime. The 
lifetime of minority carriers is sensitive to the radiation-induced defects that mostly act as recombination points, and the decrease in the minority carrier lifetime reduced the solar cells parameters.

According to the spectral photocurrent results, after $\gamma$ irradiation, the most of the performance of the cell is lost in the low wavelength of the spectrum this means that production defects due to $\gamma$ radiation occurred near the cell surface.

\section{References}

A El-Amin, A., \& Ibrahim, A. (2012). Structural, Optical, and Electrical Properties of CdTe Thin Films Deposited by Glancing Angle Deposition. Current Nanoscience, 8(5), 783-789.

Ali, A., Gouveas, T., Hasan, M.-A., Zaidi, S. H., \& Asghar, M. (2011). Influence of deep level defects on the performance of crystalline silicon solar cells: experimental and simulation study. Solar Energy Materials and Solar Cells, 95(10), 2805-2810.

Alurralde, M., Tamasi, M., Bruno, C., Bogado, M. M. n., Plá, J., Vázquez, J. F., . . Stoliar, P. (2004). Experimental and theoretical radiation damage studies on crystalline silicon solar cells. Solar Energy Materials and Solar Cells, 82(4), 531-542.

Ashry, M., \& Fares, S. (2012). Electrical characteristic measurement of the fabricated CdSe/P-Si heterojunction solar cell under radiation effect. Microelectronics and Solid State Electronics, 1(2), 41-46.

Diab, H., Ibrahim, A., \& El-Mallawany, R. (2013). Silicon solar cells as a gamma ray dosimeter. Measurement, 46(9), 3635-3639.

El-Mongy, A. A., Belal, A., El Shaikh, H., \& El Amin, A. (1997). A comparison of the physical properties of CdTe single crystal and thin film. Journal of Physics D: Applied Physics, 30(2), 161.

Imaizumi, M., Taylor, S., Hisamatsu, T., Matsuda, S., \& Kawasaki, O. (1997). Analysis of the spectral response of silicon solar cells. Proceedings of the 26th PVSC Proceedings, IEEE, 3-6.

Koster, L., Mihailetchi, V., Xie, H., \& Blom, P. (2005). Origin of the light intensity dependence of the shortcircuit current of polymer/fullerene solar cells. Applied Physics Letters, 87(20), 203502.

Kuendig, J., Goetz, M., Shah, A., Gerlach, L., \& Fernandez, E. (2003). Thin film silicon solar cells for space applications: Study of proton irradiation and thermal annealing effects on the characteristics of solar cells and individual layers. Solar Energy Materials and Solar Cells, 79(4), 425-438.

Madatov, H. M. R. (2014). Effect of Irradiation on Electrical Conduction and Crystallization in Ge1-x Six Films. Int. J. Electrochem. Sci, 9, 1179-1186.

Nema, S., Nema, R., \& Agnihotri, G. (2010). Matlab/simulink based study of photovoltaic cells/modules/array and their experimental verification. International journal of Energy and Environment, 1(3), 487-500.

Nikolić, D., Stanković, K., Timotijević, L., Rajović, Z., \& Vujisić, M. (2013). Comparative study of gamma radiation effects on solar cells, photodiodes, and phototransistors. International Journal of Photoenergy, 2013.

Radychev, N., Lokteva, I., Witt, F., Kolny-Olesiak, J., Borchert, H., \& Parisi, J. (2011). Physical origin of the impact of different nanocrystal surface modifications on the performance of CdSe/P3HT hybrid solar cells.

Razykov, T. M., Ferekides, C. S., Morel, D., Stefanakos, E., Ullal, H. S., \& Upadhyaya, H. M. (2011). Solar photovoltaic electricity: Current status and future prospects. Solar Energy, 85(8), 1580-1608.

Ringel, S., Smith, A., MacDougal, M., \& Rohatgi, A. (1991). The effects of CdCl2 on the electronic properties of molecular - beam epitaxially grown CdTe/CdS heterojunction solar cells. Journal of applied physics, $70(2), 881-889$.

Saad, A. (2002). Effect of cobalt 60 and $1 \mathrm{MeV}$ electron irradiation on silicon photodiodes/solar cells. Canadian journal of physics, $80(12), 1591-1599$. 
Sze, S. (1981). Physics of Semiconductor Devices. John Wiley, New York NY, 122-129.

Trupke, T., Green, M., \& Würfel, P. (2002). Improving solar cell efficiencies by down-conversion of highenergy photons. Journal of applied physics, 92(3), 1668-1674.

Vasic, A., Osmokrovic, P., Marjanovic, N., \& Pejović, M. (2013). Radiation Effects in Solar Cells and Optoelectronic Devices. International Journal of Photoenergy, 2013.

Vasic, A., Vujisic, M., Stankovic, K., \& Jovanovic, B. (2010). Ambiguous Influence of Radiation Effects in Solar Cells. Paper presented at the Proceedings of Progressin Electromagnetics Research Symposium Proceedings.

VASTC, A., Vujisic, M., Loncar, B., \& Osmokrovic, P. (2007). Aging of solar cells under working conditions. Journal of optoelectronics and advanced materials, 9(6), 1843-1846.

Xie, R., Kolb, U., Li, J., Basché, T., \& Mews, A. (2005). Synthesis and characterization of highly luminescent CdSe- core CdS/Zn0. 5Cd0. 5S/ZnS multishell nanocrystals. J. Am. Chem. Soc, 127(20), 7480-7488.

\section{Copyrights}

Copyright for this article is retained by the author(s), with first publication rights granted to the journal.

This is an open-access article distributed under the terms and conditions of the Creative Commons Attribution license (http://creativecommons.org/licenses/by/4.0/). 